Tropical Journal of Pharmaceutical Research March 2020; 19 (3): 467-474

ISSN: $1596-5996$ (print); 1596-9827 (electronic)

(C) Pharmacotherapy Group, Faculty of Pharmacy, University of Benin, Benin City, 300001 Nigeria.

\title{
Effect of sodium dichloroacetate as single agent or in combination with cisplatin in normal and human cervical cancer cell lines
}

\author{
Alejandro Zugasti ${ }^{1}$, Ana L Rivera1, Sonia Y Silva², Miguel A Alfaro", Crystel A \\ Sierra ${ }^{1 *}$ \\ ${ }^{1}$ Laboratory of Immunology and Toxicology, ${ }^{2}$ Department of Science in Bioactive Compounds, Faculty of Chemistry, \\ Autonomous University of Coahuila. Saltillo, Coahuila, Mexico \\ *For correspondence: Email: crystelsierrarivera@uadec.edu.mx; Tel: +52-01 (844) 4390511
}

Sent for review: 30 October 2019

Revised accepted: 26 February 2020

\begin{abstract}
Purpose: To evaluate the synergistic cytotoxicity of sodium dichloroacetate (DCA) in combination with cisplatin (CIS) against human cervical cancer cell lines.

Methods: Cervical cancer SiHa and HeLa cells and normal cells (Hek-293, Vero, peripheral blood mononuclear and human erythrocytes) were treated in vitro with DCA and CIS individually or their combination. Cell viability was determined by 3-(4,5-dimethylthiazol-2-yl)-2,5-diphenyltetrazolium bromide (MTT) method while hemolytic activity was evaluated from the released hemoglobin. Halfmaximal inhibitory concentration (IC50) of DCA or CIS was obtained.

Results: The combination of DCA + CIS decreased the cell viability of SiHa, Hek-293, Vero, and PBMC cells, but not of Hela cells $(p<0.05)$. Furthermore, the individual treatments alone or in combination did not cause significant hemolysis $(p<0.05)$.

Conclusion: The combination of DCA + CIS increases the damage caused by CIS alone on SiHa cells. It also decreases the cell viability of Hek-293 and Vero without affecting peripheral blood mononuclear and human erythrocyte integrity. The results suggest that the combination of DCA and CIS can induce synergistic antitumor effect in different types of cancer cell lines. However, further studies are required to determine the biological effects of the combination of DCA and CIS in vivo.
\end{abstract}

Keywords: Cervical cancer, Sodium dichloroacetate, Cisplatin, Viability, Hemolysis

This is an Open Access article that uses a fund-ing model which does not charge readers or their institutions for access and distributed under the terms of the Creative Commons Attribution License (http://creativecommons.org/licenses/by/4.0) and the Budapest Open Access Initiative (http://www.budapestopenaccessinitiative.org/read), which permit unrestricted use, distribution, and reproduction in any medium, provided the original work is properly credited.

Tropical Journal of Pharmaceutical Research is indexed by Science Citation Index (SciSearch), Scopus, International Pharmaceutical Abstract, Chemical Abstracts, Embase, Index Copernicus, EBSCO, African Index Medicus, JournalSeek, Journal Citation Reports/Science Edition, Directory of Open Access Journals (DOAJ), African Journal Online, Bioline International, Open-J-Gate and Pharmacy Abstracts

\section{INTRODUCTION}

Cervical cancer is a disease of high prevalence, incidence, and mortality. According to the World Health Organization (WHO) in 2018, this disease caused 570000 new cases of which approximately 270,000 women died, representing $7.5 \%$ of female mortality due to malignant tumors. Cervical cancer occurs in women of all ages, and sexual transmission of human papillomavirus subtypes (HPV-16 and HPV-18) are the primary etiologic agent $[1,2]$.

Cis-diamminedichloroplatinum (II) (cisplatin or cisplatinum) is a platinum-based compound that 
has been used in the clinical treatment of several malignancies, such as cervical, ovarian, lung, bladder, head, neck and testicular cancers [3,4]. However, long-term clinical treatment causes collateral effects such as nephrotoxicity, neurotoxicity, and myelosuppression, affecting all hematopoietic population and development of chemoresistance, leading to therapeutic failure [5]. For this reason, different compounds have been evaluated in combination with cisplatin. Some of these include Bithionol that potentiated the cytotoxicity induced by cisplatin on human ovarian cancer cell lines (A2780 and IGROV), caffeic acid in combination with CIS significantly inhibited cell proliferation of HeLa and CaSki cervical cancer cells. However, these combinations have not been effective in the clinical phase [6].

On the other hand, DCA is a pyruvate dehydrogenase kinase inhibitor that provokes cell death by apoptosis by a shift in metabolism from aerobic glycolysis to glucose oxidation [7] in some cancer cells such as breast, prostate, colorectal, and lung cancers [8,9]. Previously, we showed that DCA combined with CIS-induced a synergistic cytotoxic effect on B16F10 murine melanoma [10]. In this study, we investigated the cytotoxic effect of DCA in combination with CIS in human cervical cancer cells as well as toxicity in peripheral blood mononuclear cells and erythrocytes.

\section{EXPERIMENTAL}

\section{Sodium dichloroacetate and cisplatin}

The DCA was purchased from Sigma Aldrich (St Louis, MO, USA) and CIS (Blastolem RU®) was purchased from Medical Pharmacy MD (Monterrey, N.L., Mexico). Subsequently, all drugs were filtered and dissolved in Dulbecco's modified Eagle's medium (DMEM/F-12) (Life Technologies Gibco, Grand Island, NY, USA).

\section{Cell culture}

The human cervical cancer cell lines, SIHA (Squamous cervical carcinoma, HPV-16 positive), HeLa (Cervical adenocarcinoma, HPV18 positive), and normal cell lines, Hek-293 (Human embryonic kidney cells) and VERO (African green monkey kidney cells), were purchased from American Type Culture Collection (ATCC, Manassas, VA, USA) and maintained in DMEM/F12 supplemented with 10 $\%$ fetal bovine serum and $1 \%$ streptomycinamphotericin B solution (Sigma-Aldrich, St Louis, MO).
Isolation of peripheral blood mononuclear cells (PBMC)

All volunteers signed an informed consent agreement before participating in the study which was approved (protocol no. 102/2017) by the Ethics Committee of the Autonomous University of Coahuila, Mexico. Blood from healthy human volunteers was obtained with EDTA tubes, and followed the guidelines of Helsinki Declaration [11]. The blood was centrifuged with FicollHistopaque (Sigma, St Louis, MO, USA) at 1500 $\mathrm{rpm}$ at $25^{\circ} \mathrm{C}$ for $30 \mathrm{~min}$. The interphase layer consisted of PBMC, and it was washed twice with DMEM/F12.

\section{Cell viability assessment}

SiHa, HeLa, Hek-293, Vero cells lines $\left(5 \times 10^{3}\right.$

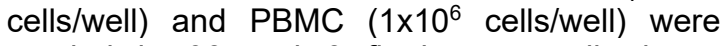
seeded in 96 and 6 flat-bottom well plates, respectively. The cells were incubated at $37^{\circ} \mathrm{C}$ overnight in $5 \% \mathrm{CO}_{2}$ atmosphere. The culture medium was discarded, and DCA was used in a concentration range from $3.66 \times 10^{4}$ to $3.66 \times 10^{5}$ $\mu \mathrm{M}$ and $\mathrm{CIS}$ in a concentration range of 0.16 to $1.28 \mu \mathrm{M}$. Cells were incubated for $72 \mathrm{~h}$, and was added MTT (Sigma, Saint. Louis, MO, USA). After $4 \mathrm{~h}$ of incubation, the supernatants were removed, and dimethyl sulfoxide (DMSO) was added to each well to dissolve formazan crystals. Absorbance was measured at $540 \mathrm{~nm}$ using a Microplate Spectrophotometer (BioTek Instruments, Inc., Winooski, VT, USA). Finally, cell viability (V) was calculated as in Eq 1.

$V(\%)=(A t / A c) 100$

where At and Ac are the absorbance of treated and control cells, respectively. The results were used to plot a concentration-response curve by linear regression to determinate the $\mathrm{IC}_{50}$ of treatments with DCA or CIS.

\section{Evaluation of the effect of DCA plus cisplatin in cervical cancer and normal cell lines}

Concentrations ranging from 0.16 to $3.66 \times 10^{5}$ $\mu \mathrm{M}$ were used for the single-drug treatment. Thus, to determine the pharmacological interaction of DCA in combination with CIS, cancer and normal cells were seeded as described above, then the $\mathrm{IC}_{50}$ of DCA was added simultaneously with the $\mathrm{IC}_{50}$ of $\mathrm{CIS}$ and incubated for $72 \mathrm{~h}$. For the case of PBMC, the $\mathrm{IC}_{50}$ of DCA was used in combination with 1.28 $\mu \mathrm{M}$ of cisplatin, because an $\mathrm{IC}_{50}$ was not obtained on PBMC treated only with cisplatin. Finally, the cell viability was evaluated by MTT assay. 


\section{Optical microscopy}

For morphological analysis, SiHa, HeLa, Hek293 and Vero cells treated with DCA, CIS alone or in combination were observed in the culture plates using an inverted optical microscope (Leica DMIL, USA) and photographs were taken with an attached camera.

\section{In vitro hemolysis assay}

The hemolysis assay was performed using human whole blood from healthy donors. The volunteers signed an informed consent agreement. Blood was collected in EDTA tubes, and centrifuged at $2500 \mathrm{rpm}$ for 4 minutes at $4^{\circ} \mathrm{C}$. The pellet was washed three times with Alsever's solution. Then, $150 \mu \mathrm{L}$ of this suspension was exposed to DCA or CIS. Finally, to evaluate whether DCA+CIS induced hemolysis, $3.66 \times 10^{5} \mu \mathrm{M}$ of DCA with $1.28 \mu \mathrm{M}$ of CIS were added to human erythrocyte culture and incubated at $37^{\circ} \mathrm{C}$ for 24 hours. The Alsever's solution and deionized water were used as negative and positive control, respectively. The samples were centrifuged at $2500 \mathrm{rpm}$ for $4 \mathrm{~min}$ and free hemoglobin in the supernatant was determined spectrophotometrically at $415 \mathrm{~nm}$ (Spectronic, model Genesis 5). Hemolysis was calculated using Eq 2.

$H(\%)=\{(A s-A n) /(A p-A n) \mid 100$

where As, An and Ap are the absorbance of sample, negative control and positive control, respectively.
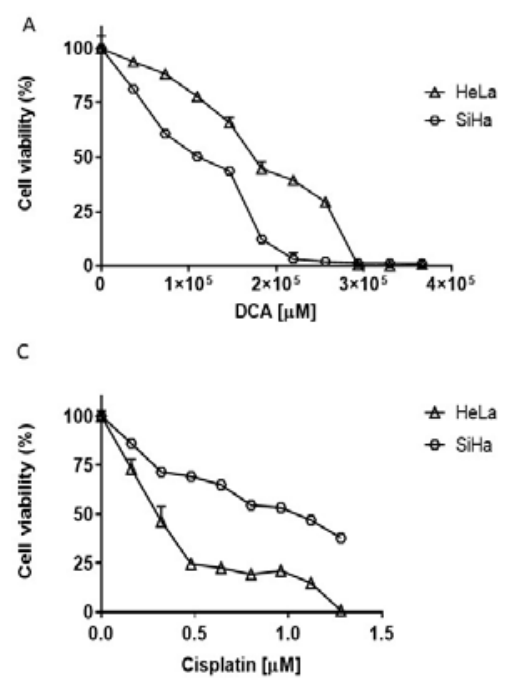

Figure 1: Cell viability of cervical cancer and normal cell lines treated with DCA or CIS. Cancer and normal cells were treated with DCA or CIS and incubated for $72 \mathrm{~h}$ at $37{ }^{\circ} \mathrm{C}$. Thereafter, an MTT assay was performed. Data represent the means of triplicate samples with \pm SD indicated. All the concentrations of DCA or CIS evaluated showed significant differences $(p<0.05)$ with respect to the untreated cells.

\section{Statistical analysis}

All experiments were performed in triplicate and data are presented as mean \pm standard deviation (SD). Statistical analysis was carried out by analysis of variance (ANOVA) followed by Dunnett's tests, using GraphPad Prism 5. The results were considered statistically significant if $p<0.05$.

\section{RESULTS}

\section{Single-agent effects on cervical cancer and normal cell viability}

The results demonstrated that DCA significantly decreased the viability of $\mathrm{SiHa}$ cells in a concentration-dependent manner, finding a $98 \%$ decrease in viability in concentrations of $2.56 \mathrm{x}$ $10^{5}$ to $3.66 \times 10^{5} \mu \mathrm{M}$. Similarly, Hek-293 and HeLa cells DCA caused a $100 \%$ reduction in viability from the concentration of $2.93 \times 10^{5} \mu \mathrm{M}$. However, in Vero and PBMC, treatment with DCA decreased cell viability by 91 and $57 \%$, respectively, at concentration of $3.66 \times 10^{5} \mu \mathrm{M}$ (Figure $1 \mathrm{~A}$ and $\mathrm{B}$ ). Therefore, SiHa was more sensitive than HeLa to DCA. On the other hand, in the $\mathrm{SiHa}$ cells, cisplatin induced a reduction on viability of $62.32 \%$ and $99 \%$ in HeLa cells (Figure $1 \mathrm{C}$ ). Similarly, cisplatin reduced the viability of Hek-293 (100\%), Vero (86\%) and PBMC (30\%) at the concentration of $1.28 \mu \mathrm{M}$ (Figure $1 \mathrm{D})$.
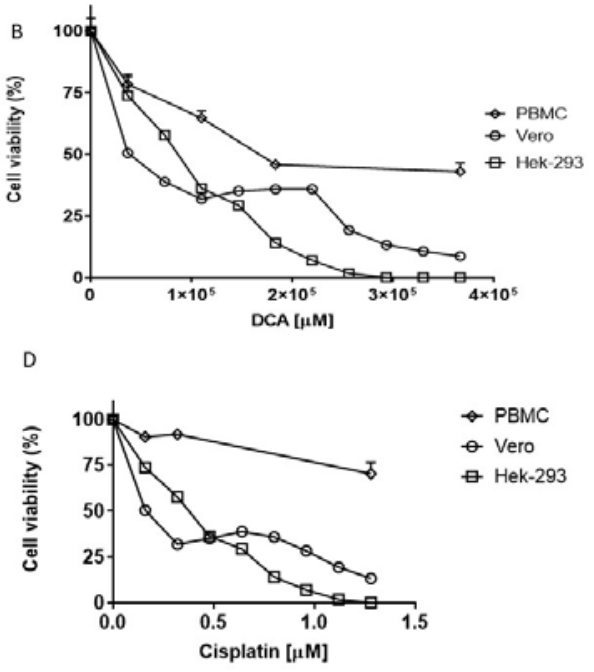
PBMC were the least sensitive to DCA or CIS compared to the rest of the cell lines evaluated. The $\mathrm{IC}_{50}$ were determined and shown in Table 1.

Table 1: $I_{50}$ values for DCA or CIS, against cancer and normal cells

\begin{tabular}{lcc}
\hline Cell type & DCA $\boldsymbol{\mu M}(\mathbf{\pm}$ SD) & CIS $\boldsymbol{\mu M}(\mathbf{\pm}$ SD) \\
\hline SiHa & $8.79 \times 10^{4} \pm 2.20$ & $0.99 \pm 0.85$ \\
HeLa & $1.98 \times 10^{5} \pm 3.25$ & $0.27 \pm 3.42$ \\
Hek-293 & $9.09 \times 10^{4} \pm 0.40$ & $0.45 \pm 0.25$ \\
Vero & $8.55 \times 10^{4} \pm 0.90$ & $0.41 \pm 1.05$ \\
PBMC & $3.63 \times 10^{5} \pm 1.58$ & $>1.28$ \\
\hline
\end{tabular}

$\mathrm{IC}_{50}$ Values were determined using linear regression $\left(R^{2}>0.9\right)$. Data are the mean $\pm S D(n=3)$

\section{Effect of DCA combined with CIS in cervical cancer and normal cells}

Cervical cancer and normal cells were simultaneously treated with $\mathrm{IC}_{50}$ of $\mathrm{DCA}$ and the $\mathrm{IC}_{50}$ of $\mathrm{CIS}$. In SiHa cells, the combinations of DCA+CIS caused a greater decrease on cell viability, maintaining only $30.69 \%$, whereas that of HeLa cells was $47.03 \%$ of live cells, compared to the single treatments (Figure 2).

On the other hand, the arrows in Figure $3 \mathrm{~A}$ and $3 \mathrm{D}$ show pyknotic cells and a decrease in HeLa proliferation to untreated cells (Figure $3 \mathrm{~B}$ ).

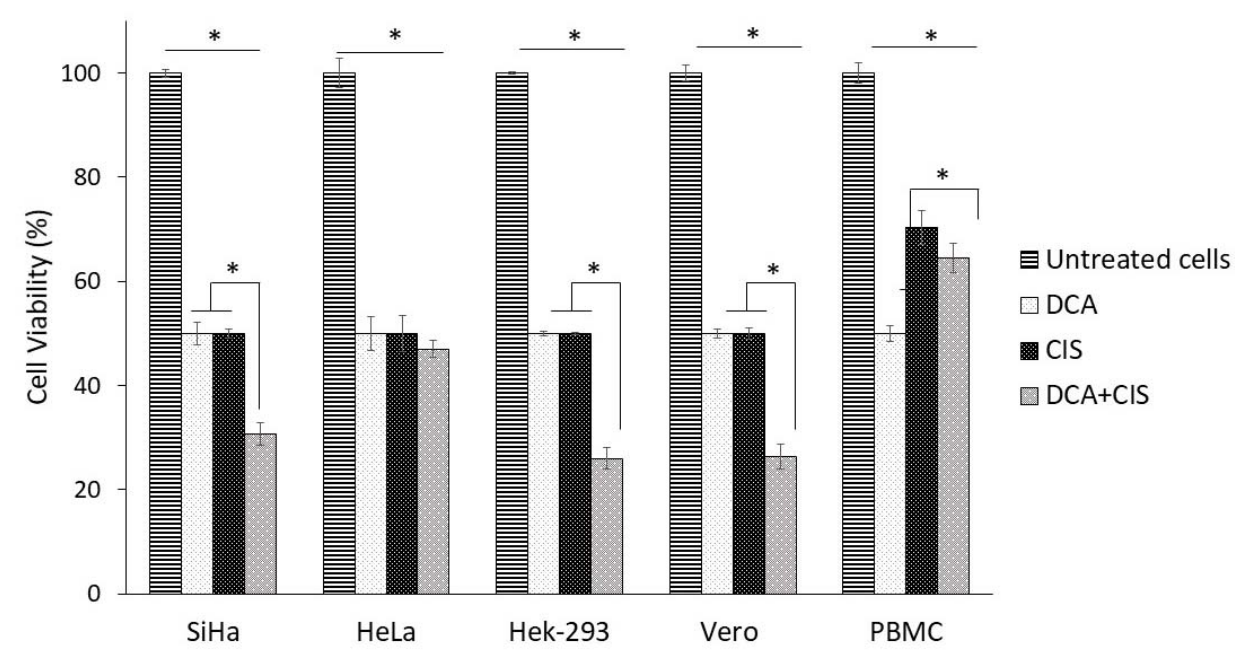

Figure 2: Effect of DCA in combination with CIS on cancer and normal cell lines. Cells were incubated with $\mathrm{DCA}+\mathrm{ClS}$ for $72 \mathrm{~h}$. Finally, an MTT assay was performed. ${ }^{*} p<0.05$ as compared with untreated cells
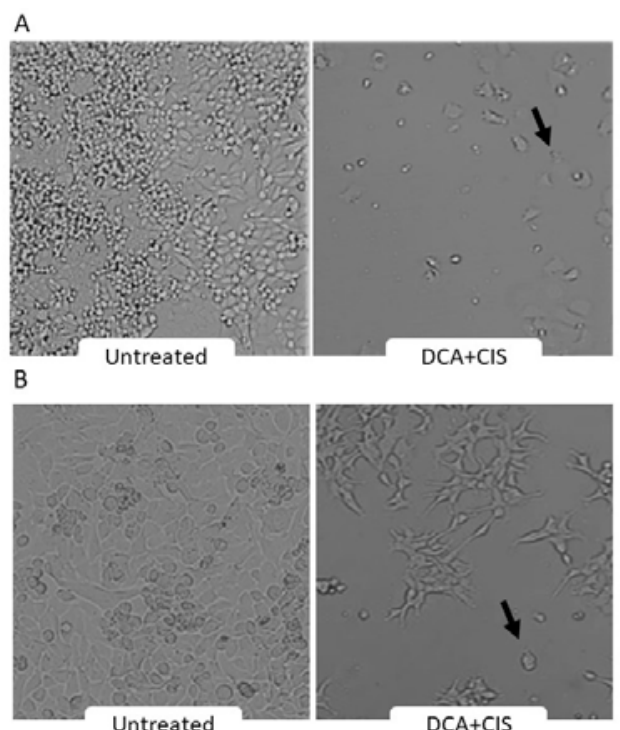

Untreated

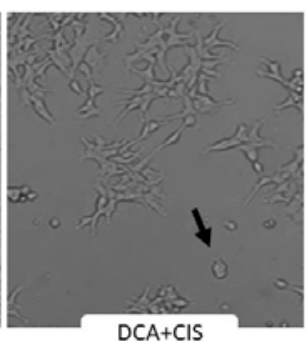

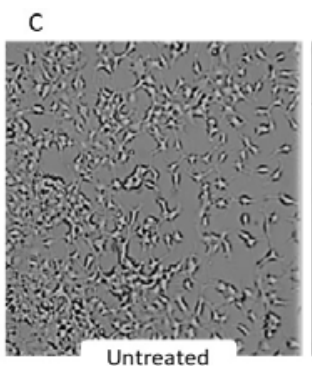

D
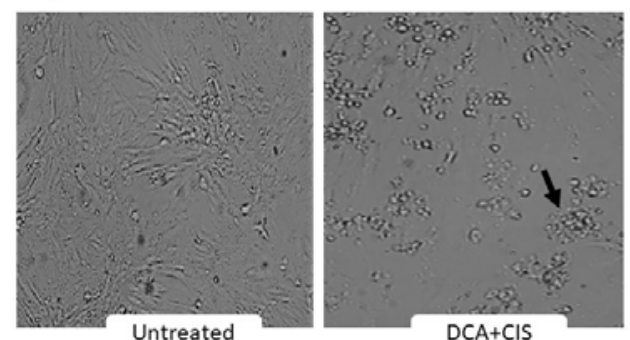

Figure 3: Morphological changes in cancer and normal cells. Cancer and normal cell lines were treated with DCA, CIS or DCA+CIS. A) SiHa cells, B) HeLa, C) Hek-293 and D) Vero cells 
A
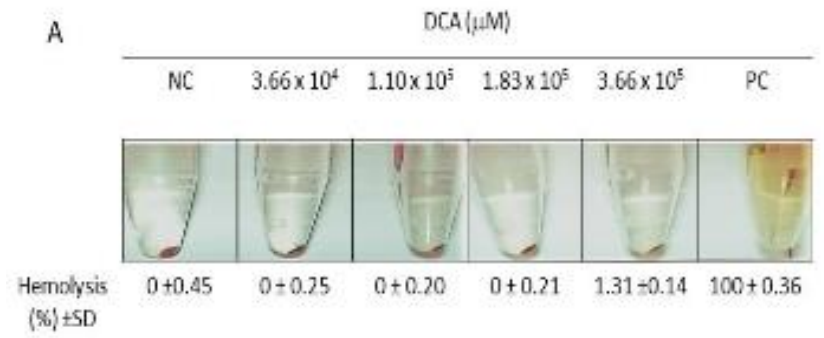

B
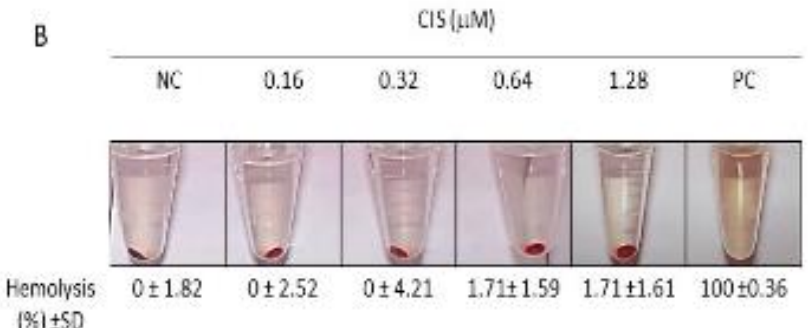

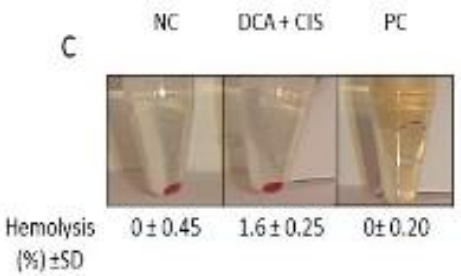

$(8)+50$

Figure 4: Hemolytic activity in human erythrocytes. A) DCA, B) CIS and C) DCA + CIS. Representative images of the results obtained are shown. Data are presented as mean $\pm S D,{ }^{*} p<0.05$. Negative control (NC) and Positive control (PC)

With respect to Hek-293 and Vero, viability of the cells was $26 \%$, contrast to PBMC that maintained the viability of $64.53 \%$ (Figure 2). These results show that the combination of DCA and CIS has a synergistic effect on SiHa, Hek293, Vero, and PBMC cells but not in HeLa cell line maintaining about $50 \%$ cell viability

\section{Hemolysis}

No significant hemolytic effects were found with the different concentration of DCA, CIS or DCA plus CIS compared to the negative control (Figure 4). The lack of hemolysis in the negative control and $100 \%$ of hemolysis in the positive control confirmed the accuracy of the assay.

\section{DISCUSSION}

There are more than 60 chemotherapeutic agents for the treatment of cervical cancer, among them CIS [12,13]. Its mechanism of action consists of the inhibition of DNA synthesis by cross-linking within and between DNA strands, causing cell death. Previous studies have found an $\mathrm{IC}_{50}$ value of $\mathrm{CIS}$ for breast cancer cell line MDA-MB-231 and SiHa cells to be 25.28 $\mu \mathrm{M}$ and $4.49 \mu \mathrm{M}$, respectively [14].

In this investigation, SiHa cell line was more sensitive to CIS compared with MDA-MB-231. It has been shown that $\mathrm{CIS}$ induces an $\mathrm{IC}_{50}$ in the concentrations of $12 \mu \mathrm{M}$ and $13 \mu \mathrm{M}$ on HeLa and $\mathrm{SiHa}$, respectively $[6,15]$. Contrary to the literature, the results obtained show that CIS at concentrations of $0.27 \mu \mathrm{M}$ and $0.99 \mu \mathrm{M}$ were the $\mathrm{IC}_{50}$ on HeLa and SiHa cells, respectively. This could be due to the difference in cell concentration and incubation times of the research protocols.

However, the SiHa cell line was more susceptible than HeLa cells to treatment with CIS at $1.28 \mu \mathrm{M}$, decreasing the viability by $99 \%$. On the other hand, $\mathrm{CIS}$ induced an $\mathrm{IC}_{50}$ at concentrations of $0.41 \mu \mathrm{M}$ and $0.45 \mu \mathrm{M}$, for Vero and Hek-293 cells, respectively. Therefore, these cell lines were more sensitive to $\mathrm{CIS}$ compared to $\mathrm{SiHa}$ cells. Also, an $\mathrm{IC}_{50}$ of $\mathrm{CIS}$ has been reported at $18 \mu \mathrm{M}$ on Vero cells [6]. However, in this work, the maximum concentration of CIS used (1.28 $\mu \mathrm{M}$ ) induced $70.34 \%$ of PBMC viability without affecting the integrity of human erythrocytes. However, an investigation conducted in 2013 concluded that $\mathrm{CIS}$ at concentrations of 1,50 and $100 \mu \mathrm{M}$ did not affect the viability of PBMC in a period of $2 \mathrm{~h}$ of incubation [16]. In a previous investigation, we found that CIS induced $8 \%$ of hemolysis in murine erythrocytes, with $1.28 \mu \mathrm{M}$ [10]. However, other investigations have found that $\mathrm{CIS}$ at $0.33 \mu \mathrm{M}$ did not cause damage to human erythrocytes [3].

Currently, it is known that solid tumors have overregulation of aerobic glycolysis for ATP molecules generation and thus have enough energy to proliferate constantly. The glycolytic phenotype inhibits apoptosis of tumor cells and resistance of several anticancer agents. Targeting this phenomenon opens a way for development to new therapeutic strategies 
against cancer, which, individually or in conjunction with conventional chemotherapeutic agents achieve to reduce tumor growth and decrease the dose of chemotherapeutic agents which may lead to a reduction in drug toxicity and increase antitumor response [17].

Some investigations have demonstrated cytotoxic effect against neuroblastoma, metastatic breast, prostate, colon, endometrial and ovarian cancer cell lines [18-21]. For this reason, we examined the effect of DCA alone on the viability of HeLa and SiHa cells. The results showed that DCA exhibited an $\mathrm{IC}_{50}$ on HeLa and $\mathrm{SiHa}$ cells at $1.98 \times 10^{4} \mu \mathrm{M}$ and $8.79 \times 10^{4} \mu \mathrm{M}$, respectively. Although both cell lines are from cervical cancer differences in the effectiveness of treatments may be due to differences in the proteome of the HeLa and $\mathrm{SiHa}$ cell lines. Recently, similarities have been found in the expression of human leukocyte antigen class proteins, actin, cathepsin D, gelsolin, keratin [22]. They also found that only $\mathrm{SiHa}$ expresses cathepsin B and glyceraldehyde 3 phosphate dehydrogenase (G3PDH), the latter actively participates in the glycolysis pathway. Therefore, the results indicate that $\mathrm{SiHa}$ line was more susceptible to DCA, this could be probably due to the $\mathrm{SiHa}$ line overexpressing G3PDH which is a therapeutic target for DCA, managing to inhibit glycolysis and consequently the proliferation of this tumor line, compared to HeLa that does not express G3PDH.

The results indicate that $\mathrm{SiHa}$, Hek-293, and Vero were similarly sensitive to the DCA. However, PBMC were resistant to DCA and the $\mathrm{IC}_{50}$ was $3.63 \times 10^{5} \mu \mathrm{M}$; with this concentration in HeLa, SiHa and Hek-293 only $1 \%$ of live cells were observed and in Vero only about $10 \%$ cell viability without affecting the integrity of human erythrocytes. In 2011 it was reported that DCA at of $2 \times 10^{3} \mu \mathrm{M}$ to $1.6 \times 10^{4} \mu \mathrm{M}$ decreased HeLa viability with a reduction of $25 \%$ of viable cells in the highest concentration [15]. Contrarily, in another investigation, it was determined that DCA at $1 \times 10^{4} \mu \mathrm{M}$ only moderately inhibited the growth of Hek-293 cell line [7].

It has been reported that the $\mathrm{IC}_{50}$ values of DCA in HeLa and $\mathrm{SiHa}$ were $7.98 \times 10^{4} \mu \mathrm{M}$ and 8.95 $\mathrm{x} 10^{4} \mu \mathrm{M}$ [23]. Similar to our results, the DCA at $3 \times 10^{3} \mu \mathrm{M}$ to $3 \times 10^{4} \mu \mathrm{M}$ moderately decreased the PBMC viability $[24,25]$. Therefore, DCA showed an antitumor effect in patients with glioblastoma and no hematological, renal, hepatic or cardiac toxicity related to the administration was observed [26]. To reduce the high doses of CIS that have been associated with the appearance of side effects, coadjuvant therapy has been suggested. This involves the use of two drugs at lower doses, and their combination will potentiate the antitumor effects of the individual drug. Thus, combination with several anticancer agents may result in a synergistic, additive or antagonistic effect. The advantage of synergism is to increase the effectiveness of the therapy and reduce the dose of the agents, reducing the toxicity of the drugs.

Therefore, based on the promising antitumor activity of DCA, we evaluated the combination with DCA + CIS on the cervical cancer cell lines. Similar to our results, a formulation denominated mitaplatin (consisting of DCA + CIS) killed tumor cells by mitochondrial damage mediated by DCA and CIS inhibited DNA synthesis on A549 lung cancer cell line at a concentration of $10 \mu \mathrm{M}$ [27]. It has been found that the combination of DCA and $\mathrm{CIS}$ showed evidence of synergy in A427 and HCC-827 human lung cancer cell lines. However, the combination of DCA and CIS did not enhance the antiproliferative action in A549 and SKLU-1 human lung cancer cell lines at concentrations of $1 \times 10^{4} \mu \mathrm{M}$ and $2 \times 10^{3} \mu \mathrm{M}$, respectively [9].

The results obtained show that $\mathrm{DCA}+\mathrm{CIS}$ combination demonstrated a synergistic effect in $\mathrm{SiHa}$, Hek-293, and Vero cells, significantly decreasing cell viability. Hek-293 and Vero are cell lines are widely used as controls for normal cells but may be more sensitive to experimental treatments due to the lack of differentiation events and phenotypic differences between species.

\section{CONCLUSION}

The findings of this study show that DCA acts synergistically with CIS on SiHa cells, but not on HeLa. The combination of DCA and CIS also significantly decreased the viability of Hek-293 and Vero normal cell lines. However, cytotoxic effects were slight in PBMC and absent in human erythrocytes. Therefore, there is a need for further investigations, clinical studies, to determine if DCA + CIS combination is a good candidate for use as an adjuvant therapy against cervical cancer.

\section{DECLARATIONS}

\section{Acknowledgement}

The authors would like to thank the Coordinación General de Estudios de Posgrado e Investigación (CGEPI) of UAdeC for their support. 


\section{Conflict of interest}

The authors declare that no conflict of interests exist with regard to this work.

\section{Contribution of authors}

We declare that this work was done by the authors named in this article and all liabilities pertaining to claims relating to the content of this article will be borne by the authors. ALRL performed the cell viability assays, AZC participated in the design of the study and drafting the manuscript, SYSB performed the statistical analysis, MAAJ carried out the hemolysis assay and CASR participated in the design and drafting the manuscript.

\section{Open Access}

This is an Open Access article that uses a funding model which does not charge readers or their institutions for access and distributed under the terms of the Creative Commons Attribution License (http://creativecommons.org/licenses/by/ 4.0) and the Budapest Open Access Initiative (http://www.budapestopenaccessinitiative.org/rea d), which permit unrestricted use, distribution, and reproduction in any medium, provided the original work is properly credited.

\section{REFERENCES}

1. World Health Organization (WHO) [Internet]. Cervical cancer; [update 2019 Oct 7; cited 2019 Oct 14]. Available from: https://www.who.int/cancer/prevention/diagnosisscreening/cervical-cancer/en/.

2. Ferlay J, Soerjomataram I, Dikshit R, Eser S, Mathers C, Rebelo M, Parkin DM, Forman D, Bray F. Cancer incidence and mortality worldwide: Sources, methods and major patterns in GLOBOCAN 2012. Int J Cancer 2014; 136(5): 359-386.

3. Mahmud H, Föller M, Lang F. Suicidal erythrocyte death triggered by cisplatin. Toxicology 2008; 249(1): 40-44.

4. Galluzzi L, Senovilla L, Vitale I, Michels J, Martins I, Keep O, Castedo M, Kroemer G. Molecular mechanisms of cisplatin resistance. Oncogene 2012; 31(15): 18691883.

5. Matsuo K, Lin YG, Roman LD, Sood AK. Overcoming platinum resistance in ovarian carcinoma. Expert Opin Investig Drugs 2010; 19(11): 1339-1954.

6. Koraneekit A, Limpaiboon T, Sangka A, Boonsiri $P$, Daduang S, Daduang J. Synergistic effects of cisplatincaffeic acid induces apoptosis in human cervical cancer cells via the mitochondrial pathways. Oncol Lett 2018; 15(5): 7397-7402.
7. Olszewski U, Poulsen TT, Ulsperger E, Poulsen HS, Geissler K, Hamilton, G. In vitro cytotoxicity of combinations of dichloroacetate with anticancer platinum compounds. Clin Pharmacol 2010; 2: 177-183.

8. Wong JY, Huggins GS, Debidda M, Munshi NC, De Vivo I. Dichloroacetate induces apoptosis in endometrial cancer cells. Gynecol Oncol 2008; 109(3): 394-402.

9. Garon EB, Christofk HR, Hosmer W, Britten $C D$, Bahng A, Crabtree MJ, Hong CS, Euw E, Black A, Michelakis $E D$, et al. Dichloroacetate should be considered with platinum-based chemotherapy in hypoxic tumors rather than as a single agent in advanced non-small cell lung cancer. J Cancer Res Clin Oncol 2014; 140(3): 443-452.

10. Rivera-Lazarín AL, Zugasti-Cruz A, Aldape de la Peña G, Silva-Belmares SY, Sierra-Rivera CA. Synergistic cytotoxic effect of sodium dichloroacetate combined with chemotherapeutic drugs on B16F10 murine melanoma cell line. BioMed Res 2019; 30(1): 179-185.

11. World Medical Association. World Medical Association Declaration of Helsinki. Ethical principles for medical research involving human subjects. Bull World Health Organ. 2001; 79(4): 373-374.

12. Ginsburg O, Bray F, Coleman MP, Vanderpuye V, Eniu $A$, Kotha SR, Sarker M, Huong TT, Allemani C, Dvaladze $A$. et al. The global burden of women's cancers: a grand challenge in global health. Lancet 2017; 389: 847-860.

13. Khalil J, Bellefqih S, Sahli N, Afif M, Elkacemi $H$, Elmajjaoui S, Kebdani T, Benjaafar N. Impact of cervical cancer on quality of life: beyond the short term (Results from a single institution): Quality of life in long-term cervical cancer survivors: results from a single institution. Gynecol Oncol Res Pract 2015; 2: 7.

14. Wang S, Xie J, Li J, Liu F, Wu X, Wang Z. Cisplatin suppresses the growth and proliferation of breast and cervical cancer cell lines by inhibiting integrin 35 mediated glycolysis. Am J Cancer Res 2016; 6(5): 11081117.

15. Xie J, Wang B, Yu D, Lu Q, Ma J, Qi H, Fang C, Chen H. Dichloroacetate shifts the metabolism from glycolysis to glucose oxidation and exhibits synergistic growth inhibition with cisplatin in HeLa cells. Int J Oncol 2011; 38: 409-417.

16. Sakai H, Kokura S, Ishikawa T, Tsuchiya R, Okajima M, Matsuyama $T$, Adachi $S$, Katada K, Kamada K, Uchiyama $K$, et al. Effects of anticancer agents on cell viability, proliferative activity and cytokine production of peripheral blood mononuclear cells. J Clin Biochem Nutr 2013; 52(1): 64-71.

17. Movva S, Rodriguez L, Arias H, Verschraegen C. Novel chemotherapy approaches for cervical cancer. Cancer 2009; 115(14): 3166-3180.

18. Vella S, Conti $M$, Tasso $R$, Cancedda R, Pagano A. Dichloroacetate inhibits neuroblastoma growth by specifically acting against malignant undifferentiated cells. Int J Cancer 2011; 130(7): 1484-1493.

19. Haugrud $A B$, Zhuang $Y$, Coppock JD, Miskimins WK. Dichloroacetate enhances apoptotic cell death via

Trop J Pharm Res, March 2020; 19(3): 473 
oxidative damage and attenuates lactate production in metformin-treated breast cancer cells. Breast Cancer Res Treat 2014; 147(3): 539-550.

20. Chaudhary AK, Bhat TA, Kumar S, Kumar A, Kumar R, Underwood W, Koochekpour S, Shourideh M, Yadav N, Dhar S, et al. Mitochondrial dysfunction-mediated apoptosis resistance associates with defective heat shock protein response in African-American men with prostate cancer. Br J Cancer 2016; 114(10): 1090-1100.

21. Li B, Li X, Ni Z, Zhang $Y$, Zeng $Y$, Yan $X$, Huang $Y$, He J, Lyu S, Wu Y, et al. Dichloroacetate and metformin synergistically suppress the growth of ovarian cancer cells. Oncotarget 2016; 7(37): 59458-59470.

22. Kontostathi G, Zoidakis J, Makridakis M, Lygirou V, Mermelekas G, Papadopoulos T, Vougas K, Gardikas A, Drakakis P, Loutradis D, et al. Cervical Cancer Cell Line Secretome Highlights the Roles Of Transforming Growth Factor-Beta-Induced Protein Ig-h3, Peroxiredoxin-2, and NRF2 on Cervical Carcinogenesis. Biomed Res Int 2017; 2017: 4180703.

23. Li B, Li X, Xiong H, Zhou P, Ni Z, Yang T, Zhang Y, Zeng $Y, \mathrm{He} J$, Yang $F$, et al. Inhibition of COX2 enhances the chemosensitivity of dichloroacetate in cervical cancer cells. Oncotarget 2017; 8(31): 51748-51757.

24. Sanchez WY, McGee SL, Connor T, Mottram B, Wilkinson A, Whitehead JP, Vuckovic S, Catley $L$. Dichloroacetate inhibits aerobic glycolysis in multiple myeloma cells and increases sensitivity to bortezomib. Br J Cancer 2013; 108(8): 1624-1633.

25. Agnoletto C, Melloni E, Casciano F, Rigolin GM, Rimondi E, Celeghini C, Brunelli L, Cuneo A, Secchiero P, Zauli G. Sodium dichloroacetate exhibits anti-leukemic activity in B-chronic lymphocytic leukemia (B-CLL) and synergizes with the p53 activator Nutlin-3. Oncotarget 2014; 5(12): 4347-4360.

26. Michelakis ED, Sutendra G, Dromparis $P$, Webster $L$, Haromy A, Niven E, Maguire C, Gammer TL, Mackey $J R$, et al. Metabolic modulation of glioblastoma with dichloroacetate. Sci Transl Med 2010; 2(31): 31ra34.

27. Dhar S, Lippard SJ. Mitaplatin, a potent fusion of cisplatin and the orphan drug dichloroacetate. Proc Natl Acad Sci USA 2009; 106(52): 22199-22204. 